\title{
Konsulat Łotwy w Wilnie i sprawozdania konsula Felikssa Donassa napisane jesienią 1939 r.
}

$\mathrm{M}$ iędzywojenna Łotwa w konflikcie bezpośrednio z nią sąsiadujących dwóch państw - Polski i Litwy o Wilno od samego początku zajęła stanowisko formalnie neutralne, ponieważ ze względu na swoje interesy państwowe chciała zachować w miarę dobre stosunki zarówno z Polską, jak i z Litwą. Było to trudne i w całości - prawie niemożliwe. W rzeczywistości już od 1920 r., nie zważając na deklarowaną formalnie neutralność, wyrażano cichą aprobatę dla zagarnięcia Wilna przez Polskę, co wywodziło się również z przekonania, że Litwa będzie pewniejszym dla współpracy regionalnej i nawet silniejszym (przede wszystkim wewnętrznie) sąsiadem bez miasta, w którym wpływy litewskie są bardzo słabe, albo wręcz znikome ${ }^{1}$. Faktycznie w Rydze uznawano przynależność Wilna do Polski i w resortowych sprawozdaniach wewnętrznych MSZ oceniano to pozytywnie. Uważano, że ewentualne, chociaż niezbyt możliwe, odzyskanie przez Litwę Wilna może tylko to państwo osłabić, to znaczy - osłabić także międzynarodowe położenie Łotwy, dla której istnienie samodzielnej Litwy, chociaż bez Wilna, miało kluczowe znaczenie. Ze względu na wrażliwość Litwinów w kwestii Wilna próbowano jednak zachować formalną, rzekomą neutralność również faktycznie (usiłowano nie nawiązywać urzędowych

1 Więcej zob.: Ē. Jēkabsons, Problem Wilna a Łotwa: jesień 1920 roku, [in:] ŁotwaPolska. Materiały konferencji międzynarodowej, red. J. Sozański, Ryga 1995, s. 68-97; idem, Latvia's position concerning the Vilnius question in the 1920's and 1930's, [in:] Lietuvos diplomatija XX amžiuje, Vilnius 1999, s. 71-82. 
kontaktów z władzami w Wilnie, mimo że było to miasto bezpośrednio tranzytowe w komunikacji z Polską, nie wysyłać do Wilna urzędowych delegacji itd.).

W rzeczywistości kontakt konsularny z Wilnem był dla państwa łotewskiego i jego obywateli, a także strony polskiej i jej obywateli po prostu niezbędny. Dlatego 18 września 1923 r. na mocy rozporządzenia rządu utworzono wicekonsulat honorowy Łotwy w Wilnie (z różnych powodów pracę rozpoczął dopiero w styczniu 1924 r.), który w październiku $1925 \mathrm{r}$. został przekształcony w konsulat honorowy. Konsulat miał jurysdykcję na terenie województwa wileńskiego, nowogródzkiego i poleskiego. To wydarzenie naprawdę zasługuje na uwage jako unikalne w historii dyplomacji, ponieważ formalnie ta instytucja była konsulatem honorowym, natomiast faktycznie - konsulatem, którego pracownicy na czele z samym konsulem, w odróżnieniu od pozostałych konsularnych przedstawicielstw honorowych, byli zawodowymi dyplomatami na etacie w MSZ Łotwy. Było to spowodowane właśnie próbą niedrażnienia opinii litewskiej przez tworzenie normalnego konsulatu w mieście, którego przynależność państwowa, jak uważano w Kownie, jeszcze nie została rozstrzygnięta w należyty sposób. Wobec tego wicekonsul, później konsul, Felikss Jānis Sergejs Donass, który został przeniesiony z Warszawy do Wilna jako zawodowy dyplomata, formalnie był jedynie konsulem honorowym. Sam we wspomnieniach pisał, że przed wyjazdem do Wilna był świadom, że czeka na niego „ciężka i delikatna sytuacja. Tam skrzyżowały się przeciwne i napięte stosunki kilku narodów. Tam znajdowała się i aktywnie działała baza wrogich nam byłych ziemian Łatgalii ${ }^{2}$. Miałem zamiar próbować ustanowić przyjazne stosunki także z miejscowymi Litwinami, oczywiście nie przekraczając dopuszczalnej granicy, przecież byłem akredytowany przy rządzie polskim”3.

W ciaggu kilkunastu lat konsulat w Wilnie w miarę poprawnie radził sobie z tą skomplikowaną i delikatną sytuacją, nawet mimo dosyć napiętych

${ }^{2}$ Łatgalia (po łotewsku: Latgale) - wschodnia czesść Łotwy, byłe Inflanty polskie. O ogólnym znaczeniu i postawie byłego polskiego ziemiaństwa polskiego Łatgalii w stosunkach łotewsko-polskich w okresie międzywojennym więcej w: $\overline{\mathrm{E}}$. Jēkabsons, Zaangażowanie państwowo-polityczne szlachty polskiej z Latgalii w pierwszej ćwierci XX wieku, „Przegląd Wschodni", 1997, t. 4, z. 3 (15), s. 513-522.

${ }^{3}$ F. Donass, Politiskos krustceļos. Atminas un vērojumi divdesmitgadīgā diplomātiskikonsulārā dienestā, Chicago 1969, s. 22-23. Wymienione wspomnienia pod tytułem „Na politycznych skrzyżowaniach. Wspomnienia i obserwacje na dwudziestoletniej służbie dyplomatyczno-konsularnej” są bardzo ważnym źródłem, także w historii Polski i Litwy. 
stosunków miejscowych władz polskich z miejscowym społeczeństwem litewskim. W latach 30., w chwilach napięć w relacjach łotewsko-polskich z powodu rzekomo złego stosunku władz łotewskich do mniejszości polskiej (jesienią 1931 r. i w 1935 r.), konsulat stał się obiektem niezadowolenia narodowo nastrojonej polskiej młodzieży akademickiej (przy konsulacie odbywały się wrogie demonstracje, kilkakrotnie ucierpiały nawet szyby budynku - zostały wybite ${ }^{4}$, jednak w sumie stosunki konsulatu z władzami polskimi były bardzo poprawne. Po likwidacji niepodległego państwa polskiego, jesienią 1939 r., zakończyło się to okupacją miasta i jego okolic przez Związek Radziecki, który później przekazał go Litwie. W czerwcu 1940 r. ZSRR całkowicie zlikwidował niepodległość trzech krajów bałtyckich, dokonując ich pełnej okupacji.

Przez 17 lat konsulem w Wilnie był zawodowy dyplomata Felikss Donass. Urodził się 12 sierpnia 1882 r. w rodzinie pisarza zarządu gminy wiejskiej Jaungulbene w guberni liflandzkiej, ale wkrótce potem jego rodzice w sprawach służbowych przenieśli się do Warszawy. Po ukończeniu kościelnej luterańskiej szkoły w Warszawie i szkoły realnej w Łowiczu w 1903 r. rozpoczął studia w Warszawskim Instytucie Politechnicznym (na wydziale inżynierii górskich), ale w 1905 r., w związku z wydarzeniami rewolucyjnymi (zamknięciem przez władze instytutu po strajkach studenckich), przeniósł się do Instytutu Górskiego w Petersburgu. Podczas studiów trzy lata praktykował jako robotnik w kopalniach w Dąbrowie w Polsce, gdzie zapoznał się z pracą pod ziemią. Studia zakończył już w trakcie I wojny światowej - w 1915 i 1916 r. rozpoczął pracę jako technik, nadzorca prac budowy rosyjskiej twierdzy morskiej w Rewlu (dzisiaj - Tallinn w Estonii). Do Łotwy, już jako niepodległego kraju, Donass powrócił w 1919 r. i we wrześniu zaczął pracę w zarządzie budowlanym portu ryskiego. Jednak już w listopadzie tego roku, w związku z utworzeniem misji dyplomatycznej Łotwy w Polsce, Ministerstwo Spraw Zagranicznych szukało inteligentnych ludzi, znających język polski i nadających się do pracy dyplomatycznej. Takie warunki spełniał Felikss Donass. Został przyjęty do pracy w Ministerstwie Spraw Zagranicznych jako referent w misji dyplomatycznej w Warszawie (na początku 1921 r., w związku z udzielonym przez Polskę przyznaniem de iure dla Łotwy, misja została przemianowana na posel-

\footnotetext{
${ }^{4}$ Zob. bardziej szczegółowo na ten temat w: Ē. Jēkabsons, Krīze Latvijas un Polijas attiecībās 1931. gadā un tās atrisinājums, „Latvijas Vēstures Institūta Žurnāls”, 1996, Nr. 4, s. $118-137$.
} 
stwo), a od marca 1920 r. pełnił w niej funkcję II sekretarza. Podczas swego długiego urzędowania w Wilnie jako konsul spisał się w sumie bardzo poprawnie, o czym świadczy także pozytywna opinia o jego pracy w MSZ Łotwy (znalazło to zresztą wyraz również w jego długoletniej pracy na tym stanowisku). Nie bez znaczenia w relacjach konsula $\mathrm{z}$ władzami polskimi był czynnik sprzyjający stosunkom towarzyskim ze społeczeństwem polskim miasta - jego żona była Polką, a dzieci uczyły się w katolickim gimnazjum, później - studiowały na Uniwersytecie Stefana Batorego. Pozostał na stanowisku konsula także po wcieleniu Wilna do Republiki Litewskiej jesienią 1939 r., aż do okupacji Litwy przez Związek Radziecki latem 1940 r.

W sierpniu 1940 r. konsulat Łotwy w Wilnie został zlikwidowany, a Donass oddelegowany do centrali jeszcze nadal formalnie istniejącego MSZ w Rydze, natomiast w październiku tego roku został formalnie zwolniony z pracy w związku z całkowitą likwidacją niepotrzebnego już władzy okupacyjnej resortu. Udało mu się uniknać represji radzieckich i podczas okupacji niemieckiej w latach 1941-1944 pracował w Rydze w biurze szefa Kontroli samorządu łotewskiego Generalnego Okręgu „Lettland” (utworzonej na podstawie i zasadach byłej Kontroli Państwowej Łotwy) jako starszy referent. W 1944 r. wraz z rodziną jako uchodźca wojenny udał się do Niemiec, a potem, po dłuższym pobycie w obozach „osób przemieszczonych" (displaced persons), wyjechał do USA, gdzie zmarł 27 lipca 1971 r. w Chicago 5 .

Sprawozdania Felikssa Donassa z Wilna pokazują skomplikowaną sytuację i wydarzenia w mieście na początku II wojny światowej widziane oczami łotewskiego konsula, okupację radziecką, reakcję na nią różnych grup społecznych i wejście armii litewskiej jesienią 1939 r. Ukazują także sytuację konsulatu Łotwy - państwa, które już w pierwszym dniu wojny (1 września) deklarowało swoją neutralność w tym konflikcie 6 . Jak w każdym historycznym źródle podobnego rodzaju należy brać pod uwagę okoliczności jego powstania oraz kompetencję autora - niewątpliwie największą

5 Latvijas Valsts vēstures arhīvs (Państwowe Archiwum Historyczne Łotwy, dalej: LVVA), 2570, fonds (fond, dalej: f.), 14. apraksts (opis, dalej: apr.), 337, 338. lieta (teki osobowe F. Donassa; dalej: 1.).

${ }^{6}$ Dla historiografii polskiej wydarzeń września 1939 r. bardzo interesująco przedstawiają się także sprawozdania dyplomatów łotewskich z Warszawy oraz z trasy ewakuacji do Rumunii wraz z rządem polskim. Zob. Ē. Jēkabsons, Poselstwo Łotwy w Polsce we wrześniu 1939 roku, „Przegląd Nauk Historycznych” (Łódź), 2005, nr 1 (7), s. 111-144. 
wartość przedstawia opis osobiście doświadczonych przez Donassa lub widzianych wydarzeń w mieście. Natomiast deskrypcje krążących w społeczeństwie opowieści, szczególnie o działalności polskiego rządu oraz jego członków itd., należy raczej uważać za zwyczajne kolportowanie pogłosek i jako takie można je wykorzystać, ale jedynie na przykład w badaniach nad polską myślą społeczną podczas wojny oraz po jej zakończeniu (i tylko jako źródło dodatkowe).

Ëriks Jēkabsons

$*$

\section{Dokument 1. Sprawozdanie konsula Republiki Lotewskiej w Wilnie Felikssa Donassa dla kierownika Wydziału Państw Baltyckich MSZ Vilisa Māsēnsa*. 17 września 1939 r.}

Od dwóch dni niemieckie samoloty latają nad Wilnem i zrzucają bomby. O uczynionych rozruchach i innych uszkodzeniach Pana poinformuje Pan Martinsons, ponieważ szczegółowego sprawozdania w obecnych warunkach nie mam możliwości napisać: ludzie szturmują przez cały dzień konsulat z powodu wiz i innych ,straszliwie pośpiesznych” spraw. Kiedy wychodzę do miasta dla załatwienia kilku spraw, prawie każdy raz jest alarm i obowiązkowo trzeba udawać się do najbliższego schronu albo na podwórze domu, ponieważ znalezienie się na ulicy jest surowo zakazane. Jeden z pracowników konsulatu - Gucevičs w sierpniu wyjechał do Łotwy na urlop. 1 września miał wrócić, lecz tego nie zrobił, prawdopodobnie bojąc się wojny. Dlatego nie było możliwości napisać szczegółowego sprawozdania. Dzisiaj jest niedziela i wydałem rozporządzenie, żeby nikogo nie przyjmować, żeby móc Pana przynajmniej krótko informować o tutejszych warunkach:

$[\ldots]$

Dzisiaj rano w Wilnie panuje szczególny niepokój. Wokół miasta kopią rowy przeciwczołgowe i z południowo-zachodnich przedmieść Wilna ewakuuje się ludność, niosąc w rękach, na karku swoje rzeczy.

\footnotetext{
* Vilis Māsēns (1902-1964) - dyplomata łotewski. Od 1938 r. kierownik Wydziału Państw Bałtyckich MSZ.
} 
Dopiero otrzymałem wiadomość (ze źródeł sztabowych), że bolszewicy weszli do Mołodeczna. Sztab wileński niszczy i pali tajne dokumenty.

[...]

Dopiero opisane wydarzenia całkowicie dezorientują konsulat. Zgodnie z ustnym rozporządzeniem dyrektora Stegmanisa ${ }^{1}$ pozostanę w konsulacie w każdym razie. Jak się zachować? Czy urzędy Niemiec czy Rosji radzieckiej będą respektować międzynarodowe prawa konsulatu?

Prawdopodobnie zostanie przerwana wszelka łączność. Czy ministerstwo nie mogłoby przysłać w rozporządzenie konsulatu państwowy samochód z kierowcą i większym zapasem benzyny?

Dzisiaj w konsulacie wielu młodych ludzi (studentów) żąda wizy do Łotwy, żeby trafić do Francji.

Źródło: LVVA, f. 2574, apr. 3, 1. 3248, lp. 37.

\section{Dokument 2. Sprawozdanie konsula Republiki Lotewskiej w Wilnie Felikssa Donassa dla Poselstwa w Moskwie. 29 września 1939 r.}

19 września Wilno zostało zajęte przez wojsko Związku Socjalistycznych Republik Radzieckich. Od tego czasu łączność telegraficzna, telefoniczna i pocztowa konsulatu ze światem zewnętrznym jest przerwana.

W konsulacie pozostali:

1) Konsul Felikss Donass, obywatel Łotwy,

2) Żona konsula Lidija Donass ${ }^{2}$, obywatelka Łotwy,

3) Córka konsula Renāte Donass ${ }^{3}$, obywatelka Łotwy,

4) Córka konsula Danuta Donass ${ }^{4}$, obywatelka Łotwy,

5) Syn konsula Vandalins Imanta Donass ${ }^{5}$, obywatel Łotwy,

6) Przybrany syn konsula Bohdan Rotert ${ }^{6}$, obywatel Polski,

7) Urzędniczka konsulatu Wanda Kędzierska, obywatelka Polski,

1 Arturs Stegmanis (1902-1986) - dyplomata łotewski, od 1938 r. dyrektor Departamentu Politycznego MSZ.

${ }^{2}$ Lidija Emīlija Donase (ur. Rotert; 1884-1973, Polka).

${ }^{3}$ Renāte Halina Natālija Donase (ur. 1917).

${ }^{4}$ Danuta Jolanta Viola Donase (ur. 1918).

5 Vandalins Imanta Donass (ur. 1922).

${ }^{6}$ Bohdan Rotert (ur. 1925). 
8) Jej córka Iwona, w wieku 2 lat,

9) i 10) służące.

Urzędnik konsulatu Vilhelms Gucevičs, obywatel Łotwy, 5 sierpnia wyjechał na urlop na Łotwę, z którego nie wrócił.

20 września byłem z wizytą u komendanta Wilna Starostina, a 28 września przybyłem do tymczasowego kierownika wileńskiego okręgu Żilanina ${ }^{7}$, gdzie wyjaśniłem następujące sprawy:

1) Obywatele Łotwy mogą spokojnie zostać na miejscu i kontynuować swoją zwykłą pracę;

2) ich własność na razie nie zostaje odebrana i pozostaje w ich rozporządzeniu;

3) na razie zakazano wyjeżdżać za granicę bez pozwolenia urzędów ZSRR. Zażądano instrukcji od urzędów centralnych w Moskwie. Zanim nadejda, upłynie kilka dni;

4) łączność pocztowa wznowiona jedynie na okupowanym terytorium. To sprawozdanie wyślę Wam pocztą polową. Bardzo proszę na razie wysyłać pisma konsulatowi taką samą droga;

5) tymczasowy kierownik Żilanin był na tyle uprzejmy, że obiecał odnowić telefon konsulatu $\mathrm{Nr}$ 13-34.

Na razie jest prawie niemożliwie dostać kilka artykułów żywnościowych, od czego bardzo silnie cierpią wyżej wymienieni pracownicy konsulatu i ich rodziny. Dlatego konsulat uprzejmie prosi nadesłać im jakąś drogą, z Łotwy albo Moskwy:

1) 1 beczułkę solonego, ale dobrego masła,

2) sadło,

3) tłuszcz,

4) wędzoną świninę,

5) cukier,

6) herbatę,

7) kakao,

8) wędzoną szynkę, kiełbasę, konserwy i podobne rzeczy.

Zachowanie żołnierzy bolszewickich wobec mieszkańców dobre, natomiast Niemcy zachowują się wobec mieszkańców cywilnych bezlitośnie.

Źródło: LVVA, f. 2574, apr. 3, 1. 3248, lp. 34.

7 Jakim Żilanin (1907-1979) - funkcjonariusz partyjny na Białorusi, od września do 7 października kierownik Tymczasowego Zarządu Okręgu Wileńskiego. 


\section{Dokument 3. Sprawozdanie konsula Republiki Lotewskiej w Wilnie Felikssa Donassa dla kierownika Wydziału Państw Baltyckich MSZ Vilisa Māsēnsa. 16 października 1939 r.}

W osobistej rozmowie Pan Śmigielski ${ }^{8}$ mi powiedział, że już od wielu lat walczył przeciwko przestępczemu niedbalstwu w kwestiach motoryzacji. Do Piłsudskiego ${ }^{9}$ jego nie dopuszczali. Potem władza państwowa trafiła w ręce zarozumiałych ignorantów, którzy doprowadzili Polskę do straszliwej katastrofy. Dużą rolę odgrywała także zdrada, która znalazła wyraz w bardzo wysokich kręgach, zarówno w wojskowym, jak i cywilnym resorcie. Marszałek Rydz-Śmigły ${ }^{10}$ jest pajacem. Również z innych źródeł słyszałem podobne wypowiedzi. Władysław Studnicki ${ }^{11}$ w styczniu tego roku nadesłał osobom rządzącym memoriał, w którym uprzedzał nie rozpoczynać wojny z Niemcami, ponieważ Polska nie jest do niej przygotowana i zostanie kompletnie rozbita w ciagu dwóch tygodni! To oznacza, że cywil okazał się lepszym strategiem i znawcą sytuacji od głównodowodzącego Wojska Polskiego. Sławoj-Składkowski ${ }^{12}$ był bardzo dobrym i posłusznym żołnierzem, ale całkowicie się nie nadawał na głowę rządu. Że marszałek Piłsudski na łożu śmierci mianował Rydza-Śmigłego swoim następcą - to szantaż. To wymyślał Miedziński, przyjaciel Rydza-Śmigłego. Sławoja-Składkowskiego mianowali szefem rządu, ponieważ on jest jak prostoduszny, tak i posłuszny. Beck ${ }^{13}$ jest osobą wątpliwą. Kiedy w tym roku, przed rozpoczęciem wojny, delegacja polska na czele z Kocem ${ }^{14}$ przybyła do Londynu, rozmowy zostały przerwane dlatego, że angielski

8 Jan Śmigielski - nie udało się wyjaśnić dokładniej, kim była ta postać. W dodatkach do sprawozdań są jedynie tytuły dokumentów o braku motoryzacji w Polsce, podane władzom przez J. Śmigielskiego na początku lat 30., jednak same dokumenty zostały później z konsulatu zabrane przez ich autora.

9 Józef Piłsudski (1867-1935) - polski mąż stanu, po przewrocie państwowym 1926 r. kilkakrotnie premier, minister spraw wojskowych.

${ }^{10}$ Edward Rydz-Śmigły (1886-1941) - marszałek Polski, od 1935 r. Generalny Inspektor Sił Zbrojnych.

${ }^{11}$ Władysław Studnicki (1867-1953) - skrajnie prawicowy polityk polski, ur. w Daugavpils (Dyneburg) na terytorium późniejszej i dzisiejszej Łotwy.

12 Felicjan Sławoj-Składkowski (1885-1962) - generał polski, mąż stanu, w latach 1936-1939 premier.

13 Józef Beck (1894-1944) - pułkownik, mąż stanu Polski, w latach 1932-1939 minister spraw zagranicznych.

${ }^{14}$ Adam Koc (1891-1969) - pułkownik, mąż stanu Polski, w latach 1936-1939 prezes Banku Polskiego, później minister skarbu w rządzie emigracyjnym. 
rząd zażądał całkowitej zmiany polskiego rządu i delegacji. Do Wilna zaczynają wracać $\mathrm{z}$ frontu oficerowie i żołnierze. Wszyscy straszliwie przygnębieni i pełni żalu. Ta wojna jest tak straszliwa, że to niemożliwe do wyobrażenia. Ze wszystkich stron ukazują się czołgi, a z góry bombowce, przeciwko którym żołnierze bardzo często byli całkiem bezsilni, ponieważ brakowało dział przeciwlotniczych, przeciwczołgowych i nawet granatów ręcznych. Wyżsi oficerowie wsiedli do swoich samochodów i zwyczajnie uciekli w krzaki. Niżsi oficerowie i żołnierze walczyli zgodnie z sumieniem i dobrze, jednak bez kierownictwa zaczęli rozsypywać się. Samoloty paraliżowały każde przegrupowanie w ciagu dnia, a kolumny czołgów wroga rozerwały dywizje, odcięły sztaby i amunicję od jednostek żołnierskich. Kiedy z tyłu wmaszerowała armia rosyjska, wtenczas zamęt i rozwał był całkowity i rozpoczęła się ogólna ucieczka na wszystkie strony. Wszyscy klęli na nieumiejętny rząd i kierownictwo wojskowe, a jednocześnie twierdza, że w sztabie i innych odpowiedzialnych miejscach siedzieli niemieccy agenci. Tak na przykład dowódca 133. Pułku Piechoty Wandtke ${ }^{15}$ bardzo źle mówił po polsku, a językiem w domu był niemiecki. Wielu miało podejrzane żony. Sieć szpiegów niemieckich działała doskonale. Kiedy bolszewicy zbliżali się do Wilna, setki ludzi włamywało się do naszego i litewskiego konsulatu za wizami do Łotwy i Litwy. Wystraszeni mężczyźni z przerażeniem na twarzach i płaczące kobiety zrobiły pracę konsulatu bardzo ciężką, szczególnie dlatego, że prośby nieszczęsnych ludzi musiano odrzucić, ponieważ bez pozwolenia ministerstwa konsulat wydawał wizy tylko na dyplomatyczne paszporty. Oficerowie przypominali, że pomogli odzyskać Daugavpils ${ }^{16}$. Oprócz nastraszonych i podnieconych interesantów do konsulatu przybywało także bardzo wielu podnieconych i młodych ludzi z kręgów studenckich, którzy prosili o wizy dla przejazdu przez Łotwę, żeby udać się do Francji i tam wstąpić do wojska. Wszyscy jeszcze mają nadzieję na odnowienie Polski. Damy społeczeństwa rozpowszechniają wróżbę z 1893 r., w której prawidłowo są przewidziane wydarzenia z ostatnich lat. Zostało także przewidziane, że Polska uzyska wolność, a wtedy ją napadną, „łamany krzyż i sierp z młotem”, ale mię-

${ }_{15}$ Płk Antoni Wandtke był dowódcą 133. Pułku Piechoty Rez., który wchodził w skład 33. Dywizji Piechoty Rez.

${ }^{16}$ Chodzi o łotewsko-polską operację wojskową w Łatgalii w styczniu 1920 r. przeciwko Armii Czerwonej, kiedy Wojsko Polskie zajęło Daugavpils (Dyneburg) i później przekazało to miasto stronie łotewskiej. 
dzy 1942 i 1944 r. znów odnowi się Polska, potężna, od morza do morza. Także po wejściu bolszewików przybywa wielu proszących o wizy, niektórzy bez paszportów zagranicznych, wypełniają ankiety i proszą przy pierwszej możliwości odesłać je do Rygi. Ale od 19 września konsulat jest całkowicie odcięty od świata zewnętrznego: pocztę i telegramy można wysyłać tylko do terytoriów okupowanych. Telefon odłączony. Naczelnik tymczasowego zarządu Żilanin obiecał mi telefon znowu włączyć i udzielić możliwości korespondencji z naszym poselstwem w Moskwie za pomoca poczty polowej, jednak wszystkie moje próby osiagnięcia realizacji tej obietnicy zakończyły się bez powodzenia. W takich samych warunkach znajduje się konsul generalny Litwy. On usiłował wyjechać samochodem do Kowna, lecz nie otrzymał pozwolenia od bolszewików! Wydaje się, że nas celowo izolowano.

Kiedy wejdą Litwini, spróbuję samochodem pojechać do Kowna, tam przekazać naszemu poselstwu dyplomatyczną pocztę konsulatu dla Rygi i skontaktować się telefonicznie z Ministerstwem Spraw Zagranicznych. Czy nie powinienem przybyć ze sprawozdaniem do Rygi? Nazbierało się wielu różnych takich pytań, dla wyjaśnienia których jest niezbędny osobisty kontakt.

Dodaję jedną kopertę ze sprawozdaniem z 29 września, którego nie udało się wysłać ${ }^{17}$. Pytanie o nadesłanie żywności zapewne nie będzie więcej aktualne, ponieważ mam nadzieję przywieźć wszystko z Kowna lub Rygi, jeśli ministerstwo pozwoli mi tam pojechać na kilka dni.

Źródło: LVVA, f. 2574, apr. 3, 1. 3248, 1p. 31-33.

\section{Dokument 4. Sprawozdanie konsula Republiki Lotewskiej w Wilnie Felikssa Donassa sporządzone dla ministra spraw zagranicznych Vil- helmsa Muntersa* o wydarzeniach w mieście. 1 listopada 1939 r.}

Wykonując polecenie Pana, mam zaszczyt meldować, co następuje o warunkach w Wilnie, poczynając od 12 września t.r. i kończąc z wejściem wojska litewskiego do Wilna.

\footnotetext{
17 Patrz dokument nr 2.

* Vilhelms Munters (1898-1967) - mąż stanu Łotwy, w latach 1936-1940 minister spraw zagranicznych.
} 


\section{Przegląd chronologiczny}

12 września 1939 roku do konsulatu z pierwszą wizytą przybył nowo mianowany konsul generalny Litwy Pan Trimakas ${ }^{18}$. Informowałem go o miejscowych warunkach i udzieliłem kilku praktycznych wskazówek. Po dwóch dniach odwiedziłem go z rewizytą. Między nami wytworzyły się bardzo dobre stosunki. Przed tym miejscowi Litwini „oficjalnie” bojkotowali konsulat, chociaż u mnie osobiście stosunki były bardzo dobre.

15 i 16 września niemieckie samoloty silnie bombardowały Wilno. W pierwszym dniu zrzucono koło 200 bomb, w drugim dniu - koło 300. Całkowicie zburzono radiostację i silnie uszkodzono lotnisko. Wiele bomb padło także na przedmieścia - na Antokol i Zwierzyniec, zginęło lub zostało rannych koło 100 osób cywilnych. Lotnicy ostrzeliwali miasto także z [pokładowych] karabinów maszynowych. Metalowy dach konsulatu został przedziurawiony kilkoma kulami z karabinu maszynowego.

17 września wyżsi urzędnicy wileńskich urzędów zaczęli się ewakuować. Otrzymałem pierwsze wiadomości o wejściu wojska ZSRR do Polski. Pojechałem na wieś do swojej rodziny. Rozmawiałem z dostatnimi polskimi chłopami (28 km od Wilna). Oni przeklinają polski rząd, który powinien był oddać Niemcom Gdańsk, ponieważ nie był przygotowany do wojny. Chłopi najwięcej się boją wejścia Niemców, ponieważ oni rekwirują wyroby chłopów o wiele staranniej i bezlitośniej od bolszewików. Najlepiej by było, gdyby weszli Litwini, bo pod nimi chłopi by mogli porządnie i bez strachu wytwarzać swoje wyroby i sprzedawać na miejskich rynkach.

Wysłałem z Panem Gustavsem Martinsonsem ostatnią pocztę dyplomatyczną. Do konsulatu po wizy przybywa bardzo wielu ludzi. Opowiadali, że bolszewicy zajęli Wilejkę i Mołodeczno. Meldowałem Panu o tym przez telefon.

18 września w mieście panował straszliwy niepokój. Już koło 7 nad ranem koło konsulatu stały kolejki ludzi. Od godz. 8 do 22 bez przerwy w biurze konsulatu pracował personel i wszyscy członkowie [mojej] rodziny. Koło 17 ukazało się ekstrawydanie „Głosu Narodowego” z bardzo dobrymi wiadomościami: kilka państw wypowiedziało wojnę Niemcom; w Niemczech rewolucja; Francja ultymatywnie zażądała zaprzestania działalności wojskowej Związku Radzieckiego; wojsko rosyjskie stanęło i nie

18 Antanas Trimakas - dyplomata litewski, w latach 1938-1939 radca poselstwa w Warszawie, 22 sierpnia 1939 r. mianowany konsulem generalnym w Wilnie. 
ruszy dalej. Te wiadomości wywołały olbrzymi zachwyt i radość. Masowa ucieczka zatrzymała się. Ale już za kilka godzin odkryła się prawdziwa sytuacja: bolszewicy zbliżali się do miasta. Przejście z radości na tłumiącą beznadziejność było szokujące. W związku z tym rozpadł się także plan obrony Wilna. Całą noc kontynuowano wycofanie się wojska przez Wilno. Wszyscy oskarżali administrację o umyślną dezorientację mieszkańców, żeby uciekające masy nie przeszkadzały ewakuacji wyższych urzędników i wycofaniu wojska ${ }^{19}$.

Przyjmowania telegramów poczta zaprzestała między godz. 19 i 20. O godz. 22 rozpoczęła się silna kanonada, która trwała kilka godzin.

19 września koło godz. 5 rozpoczął się huk dział i turkotanie karabinów maszynowych. Koło godz. 6 obok konsulatu przemknął pierwszy czołg rosyjski. Okazało się, że w niektórych miejscach w mieście walczyły grupki uzbrojonych w karabiny maszynowe partyzantów, którzy byli ostrzeliwani przez czołgi rosyjskie. Jedna studentka wrzuciła do czołgu butelkę z benzyną i zapalnikiem. Załoga czołgu się spaliła, studentka uciekła. W taki sposób partyzanci zepsuli jeszcze kilka czołgów. Strzelaninę w mieście było słychać przez cały dzień. Po godz. 10 przeszedłem się po mieście. Kolumny czołgów poruszały się po ulicach i zajmowały posterunki na rogach ulicznych.

Na rogach ulic Mickiewicza ${ }^{20}$ i Wileńskiej zebrali się miejscowi komuniści, ich zwolennicy i wielu ciekawych, przeważnie Żydów i osoby o wątpliwym wyglądzie, razem koło paręset ludzi. Oni okrzykami witali przybyszy, a Żydówki rzucały załogom czołgów czekoladę i zerwane na miejskich trawnikach kwiaty. Kiedy minął pierwszy strach, na ulicach ukazali się mieszkańcy już w większej liczbie, tłumili się wokół czołgów; między uśmiechającymi się żołnierzami i robotnikami leciały pytania i odpowiedzi. Żołnierze bolszewiccy opowiadali, że przyszli uwolnić naród od „panów”, oni narodowi będą organizowali odczyty - „my vas budjem uchitj, privezjom vam hleba i vam budet horosho"21. Było wiele twarzy mongolskich.

19 Zgodnie z rozkazem E. Rydza-Śmigłego z 17 września, oddziały Wojska Polskiego także z Wilna usiłowały udać się na granicę z Litwą i Łotwą i ją przejść. Również na Łotwie internowano około 1500 żołnierzy polskich z terenów północno-wschodniej Polski. Więcej w: Ë. Jēkabsons, Internowanie żotnierzy polskich na Łotwie 1939-1940, [in:] Internowanie żotnierzy polskich $w$ latach II wojny światowej, red. T. Dubicki, T. Panecki, Tarnowskie Góry 2004, s. 109-128.

${ }_{20}$ Adam Mickiewicz (1798-1855) - poeta polski.

${ }^{21}$ „Będziemy was uczyć, przywieziemy wam chleba i będzie wam dobrze”. 
Od samego rana ludzie zaczęli rabować żywność z magazynów wojskowych. Koło konsulatu, który znajduje się na stosunkowo cichej ulicy i niedaleko od magazynu, ludzie dwa dni nieśli worki z mąką i inną żywnością. Niektórzy Żydzi odnaleźli nawet wozy z końmi, za pomocą których rabunek można było wykonać znacznie pomyślniej i racjonalniej. Jeden z pozostawionych stróży chciał się sprzeciwić rabunkowi, ale tłum go zabił.

Bolszewicy od razu nie zajęli stacji telefonicznej. Dlatego ja miałem możliwość do godz. 13 utrzymać łączność telefoniczną z Rygą. Przedostatnia rozmowa była z Panem, ostatnia - z kierownikiem wydziału cudzoziemców Ministerstwa Spraw Wewnętrznych Panem Ābelsem ${ }^{22}$.

Rosjanie dorównali 1 złoty do jednego rubla, zakazując podnosić ceny towarów. Były wywieszone rozporządzenia, że wszyscy powinni rejestrować i oddać broń.

20 września. Bolszewicy wyłączyli wszystkie miejskie telefony. W konsulacie znów wielkie tłumy ludzi, głównie prosicieli wiz. Na ulicach wielu robotników i zwykłych ludzi, którzy z radością na twarzach rozmawiają z żołnierzami i oficerami Rosji radzieckiej. Zamożniejsze kręgi mieszkańców przygnębione i nastraszone. Koło sklepów długie kolejki. Ceny w niektórych sklepach zaczynają się podnosić. Byłem z wizytą u komendanta Wilna Starostina. On w którymś z pokojów zarządu wojewódzkiego osobiście rejestrował osoby stojące w długiej kolejce w celu oddania broni. Tamże rozmawiał ze mna, co prawda podnosząc się z krzesła, jednak nie prosząc mnie, żebym usiadł. Powiedział, że mnie co prawda nie zna, ale o mnie już słyszał. Na moje pytanie, czy także ja powinienem zgłosić swoją broń, Starostin odpowiedział, że moja broń będzie rejestrowana, jednak nie odebrana. Ale ani on, ani też ktoś inny potem nie rejestrował mojej broni. Na ulicach rozdawano wydrukowane w języku białoruskim ulotki z mową ludowego komisarza Mołotowa ${ }^{23}$ z 17 września. Opowiadają że

${ }^{22}$ Kārlis Ābels (1887-?) - urzędnik państwowy Łotwy, kierownik Wydziału Cudzoziemców Ministerstwa Spraw Wewnętrznych. Resort ten był odpowiedzialny także za znajdujących się na Łotwie polskich rolnych robotników sezonowych (jesienią 1939 r. - ok. 25 tys. osób), których znaczna część pochodziła właśnie z ziemi wileńskiej i okolicznych województw. Prawdopodobnie rozmowa dotyczyła kwestii związanych z ich położeniem na Łotwie w związku z wydarzeniami w Polsce. Więcej w: E. Jēkabsons, Uchodźcy wojskowi i cywilni z Polski na Łotwie 1939-1940, „Studia z Dziejów Rosji i Europy Środkowo-Wschodniej”, 1995, t. 30, s. 129-148. Oprócz tego F. Donass z wymienionym resortem mógł załatwiać sprawy wizowe dla obywateli polskich.

${ }^{23}$ Wiaczesław Mołotow (prawdziwe nazwisko: Skrjabin; 1890-1986) - radziecki mąż 
polska młodzież szkolna usiłuje przejść granicę litewską, mając nadzieję na przedostanie się do Francji i wstąpienie do wojska francuskiego.

21 września do Wilna przybywa coraz więcej [radzieckiego] wojska. $\mathrm{W}$ rozmowach $\mathrm{z}$ miejscową ludnością oni opowiadają, że tu długo nie pozostaną, lecz pójdą na Łotwę i do Estonii.

22 września. Na rynku bardzo mało chłopów. Przy wozach ludzie stoją w długich kolejkach. Chłopi zamiast pieniędzy żądają ubrania. W rozmowach i rozważaniach zwykłych ludzi już zauważam niepokój i trwogę z powodu braku żywności i cen.

23 września. Przed sklepami długie kolejki. Pracę rozpoczęła poczta. Wojsko wychodzi z Wilna w stronę Lidy i Grodna.

24 września. Przybyli jako uchodźcy dwaj studenci łotewscy - Jānis Šķenders i Vilis Lagzdinš̌, którzy pracowali jako praktykanci w Katowicach. Ponieważ bolszewicy nie dawali pozwolenia na wyjazd, oni mieli zamiar trafić do Łotwy na swoje własne ryzyko. Prosiłem ich, żeby poszli do wydziału państw bałtyckich [ministerstwa w Rydze] i opowiedzieli, co widzieli. Później opowiadano mi, że widziano ich w Turmontach ${ }^{24}$ i pozostawili wrażenie, że planują przejść granicę nielegalnie. Co się z nimi stało dalej, nie wiem. Rosjanie zarządzili rejestrację wszystkich samochodów. Potem u osób prywatnych i firm samochody odebrano, czasem wydając pokwitowania, obiecując zapłacić, innym razem całkowicie bez żadnych pokwitowań. Żołnierze nadal opowiadają ludziom, że teraz oni pójdą na Łotwę i do Estonii. Zaczynają ukazywać się bolszewickie czasopisma. Dołączam tutaj „Bojevoje Znamja”.

25 września. Bolszewicy w dużych ilościach kupują zegarki i odzież damską. Chłopi dzielą majątki.

O swojej wizycie u przewodniczącego tymczasowego zarządu okręgu wileńskiego Żilanina już pisałem ${ }^{25}$. [...]

27 września. W mieście wywieszono rozporządzenie Żilanina, że nie wolno nic samowolnie odbierać. Winni będą sądzeni jako rabusie. Kolejki do sklepów stają się coraz dłuższe. Żołnierze się dziwią, że wszyscy tak dobrze ubrani i dobrze żyją. W Wilnie zaczęto wydawać w języku białoru-

stanu, w latach 1930-1941 przewodniczący Rady Komisarzy Ludowych, w latach 1939-1949 komisarz i minister spraw zagranicznych.

${ }^{24}$ Turmonty (po litewsku: Turmantas) - do 1939 r. miasto i stacja kolejowa na granicy z Lotwą ze strony polskiej.

${ }^{25}$ Patrz dokument nr 2. 
skim [gazetę] „Vilenskaja Pravda”. Będzie ona wydawana także w języku rosyjskim, polskim, litewskim i żydowskim.

3 października. Z obietnic złożonych przez Żilanina żadnej nie spełniono: telefon konsulatu jeszcze nie działa; maszyna drukarska obywatela Łotwy Szełuto-Werowkina wciąż niezwrócona; tak samo nie udało mi się wysłać meldunku do naszego poselstwa w Moskwie. Załatwiając jakąś sprawę, bardzo trudno trafić do wyższych urzędników: strasznie długie kolejki, w których ludzie czekają po 2 dni. Bez kolejki wartownicy nikogo nie wpuszczają, nie zważając na żadne wyjaśnienia; żądają, by ukazano „propusk" ${ }^{26}$. W takich wypadkach zwracałem się do mijających oficerów, przedstawiałem się i prosiłem, żeby mnie zameldowali, co oni też robili. Oficerowie i żołnierze Rosji radzieckiej w ogóle zachowują się uprzejmie i są gotowi do pomocy. Inaczej jest z tak zwaną czerwoną gwardią robotniczą albo milicją, którą uformowano z miejscowych elementów, głównie Żydów. Ich zadaniem jest podtrzymywanie porządku i regulowanie ruchu na ulicach. Pełnią służbę w swoich obdartych i brudnych ubraniach cywilnych, z czerwonymi opaskami na rękawach. Ich zachowanie aroganckie.

Trwoga i niepokój wśród mieszkańców wzrasta z każdym dniem.

5 października. Do konsulatu w coraz większej liczbie przybywają prosiciele wiz. W większości nie mają oni zagranicznych paszportów, ale nie dają się odstraszyć i tak długo proszą, aż konsulat przyjmuje ich prośbę w celu odesłania do Rygi - do Ministerstwa Spraw Wewnętrznych.

Bez szczególnych pozwoleń można podróżować tylko w granicach terytorium okupowanego. Wszystkie prośby obywateli Łotwy na powrót do Łotwy zostały odrzucone. Pozwolenia otrzymali tylko niektórzy obywatele USA.

12 października. Do konsulatu przybył obywatel Łotwy narodowości żydowskiej Samuel Zelikson. Ukraińcy wypędzili go z żoną i dzieckiem $\mathrm{z}$ majątku żony w województwie lwowskim. Uciekając, porzucił on żonę z małoletnim dzieckiem i z dużymi trudnościami i barwnymi przygodami trafił do Wilna. Opowiadał, że konsul [honorowy] Łotwy we Lwowie ${ }^{27}$ 5 października został aresztowany przez bolszewików. Uchodźcy, którzy przybyli później, dementują tę wiadomość: widzieli konsula 13 października. Jedynie szyld konsulatu został zdjęty.

\footnotetext{
${ }^{26}$ Propusk (ros. przepustka).

${ }^{27}$ Konsulem honorowym Łotwy we Lwowie od 1929 r. do stycznia 1940 r. był miejscowy przedsiębiorca polski Wit Sulimirski (1874-?).
} 
13 października. W nocy wiele osób aresztowano. Wśród nich także obywatela Łotwy Szełuto-Werowkina. Powody jeszcze nie są znane. Bolszewicy wywożą cały sprzęt fabryki radiowej „Elektrit”. Chcieli to uczynić także z fabrykami monopolu tytoniu i spirytusu, ale tam robotnicy i robotnice wznieśli olbrzymi hałas, zarzucając bolszewikom, że obiecali robotnikom lepsze warunki życia i pracy, a teraz chcą ich zostawić w nędzy i bez pracy. Od tego czasu robotnicy i robotnice każdy dzień i noc dyżurowali w swoich fabrykach... i wygrali.

14 października. Wczoraj i dziś ludzie na ulicy Mickiewicza czekają na wejście Litwinów. Litewskie panie i dziewczyny czekały z wielkimi naręczami kwiatów, ale nie mogły się doczekać. Wieczorem na niektórych domach ukazały się litewskie sztandary, ale dzisiaj one przepadły. Do konsulatu przybiegają ludzie, na ulicach podchodzą znajomi, na uniwersytecie profesorowie oraz towarzysze pytają się moich córek, kiedy przyjdą Litwini. Po mieście krążą najfantastyczniejsze pogłoski: w Kownie rewolucja, władzę wziął Voldemaras ${ }^{28}$ albo komuniści, Litwini będą terroryzować miejscowych Polaków, tu znów Anglia zakazała Litwinom zajęcia Wilna. Wielu rozpoczyna uczyć się języka litewskiego.

Bolszewicy nadal wszystko wywożą: meble, zwyczajne ławy publiczne z sądu okręgowego, maszyny do pisania z urzędów, śmietniki z parków, nowe ramy okienne; opróżniają całkowicie większe magazyny żywnościowe. Wiozą ze wsi ziemniaki, furaż; ze szpitali łóżka i materace. W fabrykach nadal dzień i noc dyżurują robotnicy, żeby nie dopuścić do wywozu sprzętu. Czerwoni milicjanci rekwirują samowolnie aparaty radiowe. Ludzie coraz więcej narzekają i niepokoją się.

W rozmowie we dwójkę z robotnikami i zwykłymi ludźmi żołnierze bolszewiccy opowiadają: „My czekaliśmy, że wy przyjdziecie i nas uwolnicie od naszego nieszczęścia. Ale los was ukarał - my przyszliśmy do was ze swoim piekłem. Przecież u was tu istotny raj”.

Także oficerowie zaczynają się przyznawać, że ich okłamano o warunkach w Polsce. Na przykład komisarz, który przeprowadzał rewizję w szkołach wiejskich, nie chciał wierzyć, że w szkołach uczą się także biedni i ich uczą bez zapłaty.

${ }^{28}$ Augustinas Voldemaras (1883-1942) - polityk i mąż stanu Litwy, kilkakrotnie premier, minister spraw zagranicznych. Od 1936 r. na uchodźstwie politycznym we Francji. W 1940 r. wrócił na Litwę. 
Dzisiaj profesor [uniwersytetu] Jagmin ${ }^{29}$ opowiada, że do rektora przyszło trzech mężczyzn, dwóch w cywilu, jeden w mundurze, i pytali, kto z profesorów chce jechać do Rosji. Zachowali się bardzo swobodnie. Weszli w paltach, jeden z czapką na głowie, i usiedli w gabinecie rektora. Aresztowano 50 lekarzy: 10 Żydów, 5 Rosjan i pozostali - Polacy. Ich na pewno odwiozą do Rosji, bo lekarze im są bardzo potrzebni.

16 października. Po tym, jak weszli bolszewicy i zarządzili, że $1 \mathrm{zl}=$ $1 \mathrm{rb}$, zaczęły podnosić się ceny na towary, mimo zakazu. Na przykład masło można było dostać za oficjalne ceny w bardzo małych ilościach i tylko w 3-4 miejscach w całym Wilnie. Tam były tak długie kolejki, że ludzie czekali po 13 godzin. Towary przepadły, ale nielegalnie można dostać niektóre produkty.

Wcześniej kosztowało:

Masło $1 \mathrm{~kg}$

Jajka sztuka

Świnina $1 \mathrm{~kg}$

Wołowina $1 \mathrm{~kg}$

Ziemniaki 1 pud zł 2,80-3, 00

$$
0,07-0,08
$$$$
1,60-1,80
$$

0,80
Teraz kosztuje:

$$
\begin{gathered}
20-35 \mathrm{rb} \\
0,30 \\
14,00 \\
6,00-8,00 \\
4,00-5,00
\end{gathered}
$$

Litewski konsul, wizując paszporty naszych obywateli, zaczął dorównywać $1 \mathrm{Lt}=5 \mathrm{zl}$. Dzisiaj powiedział mi, że taki będzie kurs złotego. Wobec tego zarządziłem, żeby od 19 października także w naszym konsulacie 1 łat dorównywać 5 złotym.

19 października. Wszyscy z tęsknotą oczekują normalnych warunków. Bolszewicy nadal wywożą rzeczy. Wywieziono pieniądze z Państwowego Banku Polskiego. Z Państwowego Archiwum wywożą wszystkie akta, dotyczące Grodna i Mińska. Niektóre osoby, które były aresztowane, zwolniono. Bolszewicy rozkazali zdjąć z domów czerwone sztandary.

21 października. Ludzie coraz bardziej niepokoją się zwłoką w wejściu Litwinów. Wielu ludzi noce spędza poza domem, ponieważ boi się denuncjacji i ich skutków. Miejscowi nieprzyjaciele wykorzystują obecne warunki.

29 Janusz Jagmin (1896-1948), profesor nauk rolniczych na Uniwersytecie Wileńskim do $1939 \mathrm{r}$. 
Masło i żółty ser już pojawiają się w niektórych sklepach. Ceny masła spadły do $20 \mathrm{zł} / \mathrm{kg}$, sera $-14 \mathrm{zz} / \mathrm{kg}$. Tłuszczu i sadła jeszcze nie można dostać. Mnie obiecano jeden kawałeczek, ale 20 zł/kg. Niektórzy z odprowadzonych do Rosji polskich żołnierzy uciekli i opowiadają, że w Rosji jeszcze dłuższe kolejki i nieuprawiane pola. Stąd na razie wszystko wywożą do Mołodeczna, ale brak tam pomieszczeń i niektóre towary, jak na przykład cukier i mąkę, składują w szczerym polu. To opowiadają polscy kolejarze, których pozostawiono na ich stanowiskach pracy.

22 października. Dzisiaj rano dzwoniono z 2. komisariatu czerwonej milicji, żeby wysłać tam jakichś ludzi z konsulatu (myślano, że tu konsulat Litwy), bo ludzie włamali się do piwnic komisariatu i rabują węgiel kamienny. Milicja robotnicza (której na razie konsulat litewski płaci pensje) nie może sobie poradzić z rabusiami. Odpowiedziałem, żeby dzwonili do konsula Litwy. Rabunki mają miejsce także w porzuconych mieszkaniach. Poszedłem do 2. komisariatu spojrzeć, co tam się dzieje. Tam już stało kilka czołgów i samochodów opancerzonych. Rabunek był przerwany. Żołnierze więcej nie kupują towarów, bo wprowadzono zakaz ich wysyłania do domu.

23 października. Radio mówiło, że Mołotow pozwolił Litwinom wejść do okręgu wileńskiego. Ukazały się na kilku ulicach sztandary litewskie, nawet z papieru, ponieważ zabrakło płótna. Na ulicach, szczególnie Mickiewicza, tłumy ludzi z radością na twarzach. W kościołach dzwoniły dzwony. To nadawało publiczności ulicznej uroczyste i radosne zabarwienie. Jakaż różnica z 19 września!

Handlarzom znów nakazano otworzyć sklepy. Ukazały się dawno niewidziane precle i ciastka. Na ulicach żydowskich też tłumy ludzi, ale mniej radosne. Główna ulica żydowska (Niemiecka) zamieniła się w rzeczywistą „tołkuczkę”, gdzie teraz handlują najróżniejszym towarem: ubrania, obuwie, maszyny do pisania, sprzęt biurowy, wozy z węglem kamiennym. Prawdopodobnie jest to towar ukrywany albo zrabowany, którego ceny spadną po wejściu Litwinów. Chodzą także bolszewicy, ale bardzo rzadko coś kupują. Milicjantów czerwonych robotników widać bardzo rzadko. Oni wyjechali z bolszewikami, bojąc się zemsty ludzi. Ruch regulują czerwonoarmiści. Ukazała się odezwa komitetu powitania wojska litewskiego w pięciu językach: litewskim, białoruskim, polskim, rosyjskim i żydowskim: Armia litewska idzie, żeby dać Wilnu bezpieczeństwo, pokój i porządek. Żeby ludzie witali wchodzących. Ukazała się także odezwa nowego tymczasowego 
przewodniczącego Wilna Kraskowa ${ }^{30}$, żeby nie rabowano i nie odbierano rzeczy prywatnych. Takie przestępstwa będą karane ściśle według prawa.

24 października. W nocy robotnicy zrabowali wagony z załadowanym przez bolszewików towarem do wywozu: wódką, spirytusem, solą i innymi rzeczami. Robotnicy fabryki monopolowej jeszcze dyżurują przez dzień i noc. Jednak kasę wzajemnego zabezpieczenia robotników - 25000 zł, bolszewicy wywieźli. Teraz również byli miejscowi komuniści plują na bolszewików i przezywają ich rabusiami. Oni nie wierzyli w opowiadania o głodzie i smutnych warunkach w Rosji radzieckiej, a teraz widza, że wszystko było prawdą. Nauczono ich nienawidzić polski pański rząd i ustrój. Teraz żałują zaginięcia Polski i marzą o jej odnowieniu, wierząc, że będzie w niej panowała jednomyślność. Lepiej już wtedy pod Niemcami niż pod tymi rabusiami. Litwinów oczekują z niecierpliwością jako ratowników od koszmaru bolszewickiego, ale z wielkim niepokojem i obawa, ponieważ boją się szowinizmu litewskiego, utraty miejsc pracy, banicji, obniżenia kursu złotówki, zemsty litewskiej. Marzą o odrodzeniu Polski i rozprawie z osobami, z winy których Polska się rozpadła.

25 października. Obecnie sytuacja w kwestii bezpieczeństwa w Wilnie bardzo zła. Instytucje ZSRR nie interesują się tym szczególnie, ale kontynuują wywożenie wszystkiego, co tylko mogą. Czerwona milicja robotnicza prawie całkowicie się zlikwidowała. Pozostali tylko ci Litwini, którzy po wejściu armii ZSRR wstapili do milicji i innych organizacji jako „Zwolennicy bolszewików", żeby wiedzieć, co się dzieje, i ułatwić późniejsze przejęcie miasta dla Litwy. Jednak ich liczba była niewystarczająca, żeby zachować bezpieczeństwo. Po nocach zwykli rabusie z czerwonymi opaskami na rękawach, mianując się milicją, włamywali się do magazynów, sklepów, a na przedmieściach - także do prywatnych mieszkań. Mieszkańcy, którym odebrano broń, bronili się kijami i siekierami. Kiedy do konsulatu dotarła informacja, że rabunki miały miejsce na sąsiednich ulicach, my też zastosowaliśmy specjalne środki bezpieczeństwa. Nocą koło łóżek leżały w pełnej gotowości strzelby i siekiery.

Odchodzący żołnierze w rozmowach z miejscowymi robotnikami żałuja, że muszą odejść. Oni chętnie by tu nielegalnie pozostali, ale się boją że Polacy ich zabiją (,zarezhut”). I rzeczywiście, z wielu stron słyszałem, że w lasach jeszcze znajdują się polscy partyzanci, którzy nieprzerwanie

${ }^{30}$ Piotr Kraskow (1897-?) - funkcjonariusz partyjny na Białorusi, 7-28 października kierownik tymczasowego zarządu miasta Wilna. 
przeszkadzają oddzielnym grupom żołnierzy radzieckich. Po nocach do szpitali przywożą wielu rannych Rosjan. Szczególnie niebezpieczna jest grupa partyzancka jakiegoś pułkownika Dąbrowskiego ${ }^{31}$, w której jest koło 3000 ludzi i dużo pojazdów. Także w Puszczy Białowieskiej walczą większe siły polskie.

28 października. Wszystkie te dni wielu mężczyzn nadal spędza poza domem i z niecierpliwością oczekuje przyjścia Litwinów. Dzisiaj z samego rana konsul generalny Litwy dzwonił, że koło 12 wejdzie wojsko litewskie i prosił, żebym wziął udział w tym wydarzeniu. Moje miejsce jest na trybunie. Tam był konsul generalny Trimakas, jego pomocnik Čečotas, przedstawiciel litewskiego społeczeństwa Wilna Stašis, którego Polacy przed kilkoma latami osądzili na 1 rok więzienia, a bolszewicy też go aresztowali i odwieźli do Białegostoku. Stamtąd wrócił dopiero wczoraj. Na trybunie były jeszcze 3 panie z miejscowego społeczeństwa litewskiego z pięknymi kwiatami, które były przeznaczone dla generała Vitkauskasa $^{32}$, pułkownika Šarauskasa ${ }^{33}$ i przedstawiciela armii ZSRR. Oprócz tego na trybunie czekali przedstawiciele mniejszości: Polaków, Rosjan, Białorusinów, Żydów i Tatarów. Tamże wybuchł jeden incydent między mniejszościami: delegat tatarski, który ostatni się zgłosił, miał także ostatni mówić, ale on oświadczył, że „po Żydzie nie będzie mówił”, na co delegat żydowski odkrzyknął, że on „,po Tatarze nie będzie mówił”. Nastapiła bardzo kłopotliwa chwila. Jednak Tatar musiał mówić ostatni. Na placu Katedralnym (tam stała też trybuna) i na ulicy Mickiewicza było kilka tysięcy ludzi, którzy okrzykami radości witali wchodzące wojsko. Jednak tłum ludzi nie był tak wielki i okrzyki nie tak ogólne, jak na poprzednich wojskowych defiladach polskich. Szczególnie można to było zauważyć na innych ulicach, po których szło wojsko. Tam zabrakło Litwinów i Polacy tylko oglądali się na przechodzące wojsko, ale nie wykazywali żadnego głośnego zachwytu. Postawę Polaków charakteryzują następujące słowa,

31 Jerzy Dąbrowski (1889-1940) - podpułkownik Wojska Polskiego, dowódca oddziału partyzantów w 1919 r., w 1939 r. dowódca pułku, we wrześniu wszedł z kilkudziesięcioma ułanami do lasów augustowskich. W listopadzie 1939 r. uciekł na Litwę, po okupacji tego państwa aresztowany.

${ }^{32}$ Vitkauskas Vincas (1890-1965) - generał dywizji armii Litwy, w latach 1934-1940 inspektor armii, w 1940 r. - głównodowodzący armii, w latach 1940-1941 - dowódca 29. Terytorialnego Korpusu Strzelców Armii Czerwonej.

33 Šarauskas Jozas (1894-1941) - pułkownik armii Litwy, w latach 1930-1940 szef Oddziału Prasy i Oświaty Sztabu Najwyższego. 
które słyszałem kilkakrotnie: „Z trzech diabłów (Niemców, bolszewików i Litwinów) Litwini jeszcze są najlepsi”. Defiladzie nieprzyjemnie przeszkadzały pozostałe ciężarówki żołnierzy ZSRR, które niby demonstracyjnie mieszały się i kilkakrotnie przekroczyły defiladę. Wtedy Litwini przerwali defiladę, na trybunę przybył płk Šarauskas i prosił nas o przejście na ulicę Mickiewicza, gdzie można będzie swobodnie kontynuować defiladę.

Na ulicach pokazała się jednodniowa gazeta „Niech Żyje Litwa”.

29 października. Po dłuższym czasie była to pierwsza spokojna noc. Od samego rana na ulicach ukazały się patrole policji litewskiej w galowych mundurach, które tak znacznie różnią się od znoszonych garniturów cywilnych poprzednich żydowskich milicjantów. W mieście ukazało się jednodniowe wydawnictwo „Witaj, Litwo”.

Nie mogąc uzyskać połączenia telefonicznego z poselstwem w Kownie, o godz. 14 wyjechałem z rodziną do Kowna samochodem konsula generalnego Szwecji Korzova, który został przekazany pod moją opiekę. Koło dawnej polsko-litewskiej granicy droga bardzo niedobra i samochód się zepsuł. Wieczorem z Wilna do Kowna autobusem wracali zagraniczni dziennikarze, którzy nas odwieźli. W Wilnie w obrocie były jedynie polskie złote i rosyjskie ruble. Ale w Kownie złotych nikt nie chciał przyjmować i znaleźliśmy się w bardzo kłopotliwym położeniu. Na kolację i śniadanie musieliśmy zaciagnąć dług.

30 października. Przybyłem z samego rana do poselstwa przedstawić się Panu posłowi Sēja ${ }^{34}$, w tak krótkim czasie już memu trzeciemu bezpośredniemu naczelnikowi. Tam $\mathrm{w}$ formie awansu wypłacono mi lity i uratowano z kłopotliwej sytuacji.

31 października. Po uzyskaniu zgody Ministerstwa Spraw Zagranicznych wyjechałem do Rygi samochodem konsula szwedzkiego, który po remoncie w Szyrwintach przybył do Kowna.

Litewskie urzędy wszędzie wykazywały wobec mnie dużą uprzejmość i gotowość pomocy. Do Rygi dojechaliśmy koło godz. 21. Przywiezione złote okazały się tu całkowicie bezwartościowe. Nie wiem, co z nimi począć. W związku z tym osobiście będę miał duże straty, jeśli rząd mi nie pomoże.

${ }^{34}$ Ludvigs Sēja (1885-1962) - dyplomata łotewski, poseł na Litwie od września 1934 do lata $1940 \mathrm{r}$. 


\section{Handel}

Kiedy Niemcy bombardowali koleje i mosty, zaczęły się przeszkody w dostarczeniu towarów. Ludzie zaczęli kupować sól, cukier, naftę i inne rzeczy w niezwykłych ilościach. Później okazało się, że ich kalkulacje były prawidłowe: zatrzymały się dostawy tych towarów z centrów przemysłowych zachodniej Polski, spadł kurs złotego, chłopi nie chcieli nic sprzedawać za pieniądze, a żądali soli, cukru, nafty, ubrań, a najchętniej tytoniu (machorki). Kto w czas zabezpieczył się takim towarem, nie musiał cierpieć głodu. Kiedy weszli bolszewicy, zrównali 1 złoty do 1 rubla, zakazując podnoszenia cen. Żołnierze mieli dużo pieniędzy i za $1 \mathrm{rb}$ mogli kupić towar, którego wartość faktyczna była 4, 3 razy wyższa, bo przed ich wejściem $1 \mathrm{rb}-0,23$ zł. Dlatego wszystko wydawało się im niezwykle tanie i stosunkowo szybko opróżnili sklepy od pozostałych towarów. Małe zegarki ręczne, długopisy, towary tekstylne i obuwie zostały c a ł k o w i c i e wykupione. W niektórych wypadkach żołnierze zatrzymali na ulicy panie i zaczęli interesować się ich zegarkami ręcznymi. Ile taki kosztował, niech im sprzedadzą. Niektóre panie też sprzedawały, inne oddawały za darmo, ale jeśli nie chciały, nie oddawały, i żołnierze z ubolewaniem szli dalej, nie używając przemocy, bo im surowo zakazano czynić szkodę cywilnym mieszkańcom. W sklepach zegarmistrzowskich żołnierze i oficerowie kupowali po 5 zegarków, prawdopodobnie jako prezenty dla swoich znajomych. W sklepach galanteryjnych kupowali też różne towary w dużych ilościach, jak niby „,bez razboru” ${ }^{35}$. Wyszywane jedwabne trykotowe damskie koszule nocne również były bardzo popularne - jako suknie balowe. Od kilku stron słyszałem, że w teatrze w pierwszych rzędach rzeczywiście siedziały damy bolszewickie właśnie w takich toaletach wieczorowych. Z tych sklepów, których właścicieli uciekli albo wyjechali, towary zostały obłożone aresztem i wywiezione do Rosji. Po wysprzedaniu towarów handlowcy zamykali swoje sklepy, ale Rosjanie, uważając, że towar został schowany, wydali zarządzenie, że sklepy powinny być obowiązkowo otwarte. W przeciwnym razie właścicielom będą odebrane licencje handlowe. Potem wielu handlowców oddało urzędom bolszewickim swoje licencje handlowe, a pozostali otwierali każdego dnia na kilka godzin swoje puste sklepy. Jedynie jabłka można było dostać. Z chłopami, jak już zaznaczyłem, zaczął się handel wymienny. Mieszkańcy miasta sami musieli jechać na wieś po żywność. Odnowił się tak zwany zawód workowników

\footnotetext{
${ }^{35}$ Bez wyboru, oceniania.
} 
(„meschochnikow”). Częstokroć mieszkańcy przedmieść odbierali albo odkupywali za narzucone ceny od chłopów wiejskie towary, które były przewidziane dla rynku lub zamówione przez mieszkających w centrum „burżujew”. Piekarniom chleba, sklepom masła, mięsa i podobnych towarów udzielano tak mało, że mogły zaspokajać potrzeby małej części kupujących. W takich sklepach towar sprzedawano po starych cenach. Dlatego tworzyły się przy nich strasznie długie kolejki. Ludzie czekali po 3, 4, 5 i nawet 13 godzin! I do tego częstokroć na próżno, bo towaru było za mało. Jeśli nie udało się kupić towaru nielegalnie, wtedy ceny były wprost fantastyczne, na przykład $1 \mathrm{~kg}$ masła - 30 zł. Kilka dni przed wejściem Litwinów w niektórych sklepach zaczęły pojawiać się takie towary, jak mięso, masło, jajka, jednak po swobodnych cenach, na przykład masło i tłuszcz za 20 zł. Ale takich towarów, jak cukier, sól i nafta, w ogóle nie można było dostać. Taka była sytuacja do 29 października, kiedy wyjechałem z Wilna do Kowna.

III. Metody bolszewików

Wchodząc do Polski, wojsko ZSRR do mieszkańców i rozbrojonych żołnierzy odnosiło się uprzejmie i życzliwie, ponieważ „przychodzą uwolnić naród od polskich panów i ratować ludność od niemieckich bombardowań”.

\section{Na wsi}

Ze wszystkich grup mieszkańców najwięcej ucierpiało ziemiaństwo. Chłopi, do których ziemianie odnosili się źle, zrabowali majątki i zamordowali właścicieli. W kilku wypadkach przechodzące obok bolszewickie wojsko uratowało ziemian od śmierci, aresztując ich i odprowadzając, a później zwalniając. Były nawet wypadki, kiedy wojsko strzelało do rabusiów. Kilku chłopów wypędziło właścicieli z majątków, mordując ich, a pozostałą własność i ziemie podzieliło między sobą. Jeśli stosunki wzajemne były dobre, wtedy ziemianom pozostawiono kilka pokoi, 1 konia, kilka krów, kilka hektarów ziemi, wydając każdego dnia dawkę żywności (,pajok”). Organizowano komitety wiejskie, które regulowały wiejskie życie. Po jakimś czasie przyjaźnie nastrojeni chłopi uprzedzali jednak pozostałych w majątkach ziemian i doradzali uciekać. I rzeczywiście, wieś zaczęli objeżdżać nowo mianowani komisarze, głównie Żydzi, i uczyć, co robić z odebranymi majątkami. Na zwołanych wiecach na przykład odbywały się takie rozmowy: 
Komisarz: „Nu chto, pokonchili s pomeshchikami? ${ }^{36 ”}$.

Chłopi: „Da, pokonchilji” ${ }^{37}$.

Komisarz: „A kak zhe vi pokonchili?”38.

Chłopi: „Radjelilji zemlju i inventarj i dalji pomeshchiku svoju dolju”39.

Komisarz: „Ploho sdelalji. Pokonchitj - znachit ubitj pomeshchikov”40.

Były też wypadki, kiedy niektórzy chłopi odwozili żywność do miast ziemianom, którzy uciekli.

\section{$\underline{\text { Miasta }}$}

Zamożne kręgi i inteligencja z niepokojem i obawą czekały wejścia bolszewików, ale uspokoiły się, kiedy widziały, że wojsko ZSRR zachowuje się w stosunku do ludności przyjaźnie i życzliwie. Bolszewicy sami opowiadali: „My uzhe nje te, kakimi bilji 20 ljet tomu nazad. My njesjom vam kuljturu"41.

Zamiast policji organizowała się ochotnicza milicja - „Czerwona robotnicza gwardia”. Wstapili do niej głównie ludzie niezadowoleni i wrogo nastawieni do poprzedniej władzy i ustroju. Na kierownicze stanowiska trafili w większości Żydzi. Wśród mieszkańców pojawił się niepokój i pogłębiła się nienawiść do Żydów. Okazało się, że wśród rosyjskich żołnierzy są antysemici. Kiedy Żydówki obrzucały wchodzące czołgi kwiatami, niektórzy żołnierze odrzucali je z powrotem. Milicjanci narodowości żydowskiej bardzo arogancko i wyzywająco zachowywali się w stosunku do rozbrojonych żołnierzy polskich. Na przykład jakiś polski żołnierz niechcący natknął się na Żyda-milicjanta. Tamten uderzył nieuważnego żołnierza, nakrzyczał na niego i nazwał ,chamem”. Wmieszał się przechodzący obok oficer ZSRR. Wyjaśnił okoliczności incydentu, zawołał milicjanta na bok, wyciagnął rewolwer i zastrzelił Żyda. Na ulicy Kalwaryjskiej jakiś podejrzany typ zatrzymał jednego pana i odebrał mu palto. Obrabowany zwrócił się do przechodzącego obok oficera. Ten dogonił rabusia, kazał oddać palto i zastrzelił go. Takie wydarzenia wywołały pewną sympatię do wojska ZSRR. Miejscowi komuniści podali tymczasowemu zarządowi okręgu spis osób, których należało niezwłocznie aresztować. Zarząd odrzu-

${ }^{36}$ „No co, załatwiliście z ziemianami?”

37 „Tak, załatwiliśmy”.

38 „A jak żeście załatwiliście?”

${ }^{39}$ „Podzieliliśmy ziemię i inwentarz i daliśmy ziemianinowi jego część”.

40 „Źle zrobiliście. Załatwić oznacza - zabić ziemianina”.

${ }^{41}$ „My już nie ci, co przed dwudziestu laty. My niesiemy wam kulturę”. 
cił ten spis. Potem przybyło GPU ${ }^{42}$, któremu miejscowe elementy zaczęły składać denuncjacje przeciwko konkretnym osobom, częstokroć z powodu osobistych porachunków. Wtedy rozpoczęły się areszty i sądy. Członkom rodzin aresztowanych urzędnicy GPU powiedzieli, że oni sami nie są winni aresztowań: przychodzi bardzo wiele denuncjacji od miejscowej ludności. Jeśli zostaje podane takie oskarżenie, nawet anonimowe, wtedy, zgodnie z prawem Rosji radzieckiej, sprawa ma być przekazana do prawnego załatwienia i oskarżony powinien być aresztowany.

W fabrykach organizowano komitety robotnicze. Zarząd tymczasowy wydał zarządzenie, że samowolnie nic nie wolno odbierać i wszystkie fabryki powinny kontynuować pracę. Kiedy fabrykanci zwrócili się do władz z uwaga, że brakuje surowców i paliwa, odpowiedziano im: „To wasza sprawa. Jeśli fabryka zatrzyma pracę, was oddadzą pod sąd za sabotaż. Tam się wyjaśni, kto jest winny".

W mieście wywieszono zarządzenie, że wszystkie urzędy powinny kontynuować pracę i że niech każdy wraca na swoje miejsce pracy. W każdym banku, każdym urzędzie mianowano specjalnego komisarza, prawie wyłącznie Żyda. Posiadający wkłady mogli wybrać po 100 zł co pół miesiąca, później tylko po 50 zł. Koło Pocztowej Kasy Oszczędnościowej stały bardzo długie kolejki. Ludzie musieli czekać po 8-12 godzin. Wtedy otrzymywano kartkę z numerem na następny dzień. Wszystkim bankom nakazano oddać przechowywane w sejfach wartości osób prywatnych, a pieniądze wpłacić do Państwowego Banku Polskiego. Uciekając na Litwę, wojewoda wileński Maruszewski ${ }^{43}$ wywiózł z Państwowego Banku złoto, nie wystawiając żadnego pokwitowania, ponieważ „teraz nie czas dla takich drobiazgów". Ale takie drobiazgi kosztowały życie dyrektora Państwowego Banku Sierosławskiego. Kiedy bolszewicy nie znaleźli złota i waluty zagranicznej i dowiedzieli się, że część pieniędzy została spalona, aresztowali dyrektora i wyższych urzędników. Ponieważ dyrektor nie mógł przedstawić pokwitowania o wydaniu złota oraz zarządzenia o spaleniu pieniędzy, bolszewicy myśleli, że pieniądze gdzieś schowano. Intensywnym śledztwem doprowadzili oni dyrektora do takiego załamania nerwowego, że ten nie wytrzymał i na drugi dzień wyskoczył przez okno z trzeciego piętra. Straszliwie pokaleczony, zmarł po kilku godzinach. Sami bolsze-

2 Państwowy Zarząd Polityczny.

${ }^{43}$ Artur Tomasz Maruszewski (1886-1945) - pułkownik Wojska Polskiego i urzędnik państwowy, od 1935 r. wojewoda poznański, od maja 1939 r. - wileński. 
wicy przyznali, że on był „chestny chelovek"44 i wiernie służył swemu rządowi. Rodzinie powiedziano, że wraz ze śmiercią dyrektora sprawa ta została zamknięta. Rodzinę zostawiono w spokoju i nie przeszukano jego gabinetu, chociaż w innych pomieszczeniach dokonano rewizji. Nawet mianowany komisarz nie używał gabinetu nieboszczyka dyrektora, zachowując się z szacunkiem. Wicedyrektora odwieźli do Rosji. Przed wejściem Litwinów bolszewicy wywieźli wszystkie znajdujące się w Państwowym Banku pieniądze, maszyny do pisania i inny sprzęt do Rosji. Przed wejściem bolszewików dyrekcja wypłaciła urzędnikom trzymiesięczną pensję. Mianowany komisarz odebrał nie tylko tę naprzód wypłaconą pensję, lecz także skonfiskował kapitał Towarzystwa Wzajemnej Pomocy Urzędników. Kiedy tymczasowy zarząd dowiedział się o tym, kazał komisarzowi oddać pieniądze urzędnikom, a także kapitał Towarzystwa Wzajemnej Pomocy.

O wywozie sprzętu fabrycznego i innego już pisałem w 1 części - w przeglądzie chronologicznym.

W oddzielnych rozmowach żołnierze i nawet oficerowie przyznali się, że nie mówiono im prawdy o sytuacji za granica. Teraz widzą, że tu ludzie żyją o wiele lepiej niż w Rosji. Mnie opowiadano, że jedna komunistka straciła rozum i biegnąc po ulicy z potarganymi włosami, krzyczała: „Nas obmanyvali; Nas 20 ljet obmanyvali!"45.

Wydaje się, że w Rosji brakuje lekarzy i różnych specjalistów, ponieważ bolszewicy namawiali ich, żeby jechali do Rosji; tam im będą płacić pensję. Tym, którzy nie chcieli, wprost mówiono: „My i tak vas zaberjom”46 i wielu uprowadzono.

Kiedy już było wiadomo, że okręg wileński będzie oddany Litwie, miejscowi komuniści nadal chcieli jednak zorganizować głosowanie ludu za przyłączeniem do ZSRR. Pracownicy zarządu miejskiego i innych urzędów komunalnych otrzymali zarządzenie, żeby obchodzić wszystkie mieszkania i ułożyć spisy wyborców. Także do konsulatu przybył taki pracownik magistratu, żeby wpisać do spisu wyborców. Wpisał służące.

W swoim chronologicznym przeglądzie już zaznaczyłem, że stopniowo w ludziach zakorzenił się negatywny stosunek do ustroju bolszewickiego i tęsknota za normalnymi warunkami oraz nienawiść do Żydów, kiedy przyjdzie istotna chwila. Nawet miejscowi komuniści przyznają się, że

44 Uczciwy człowiek.

45 „Nas oszukiwali. Nas 20 lat oszukiwali!”

46 "My i tak was weźmiemy”. 
byli okłamywani, jeśli chodzi o warunki życia w Rosji radzieckiej. Teraz widzą, że tam panuje bieda i głód. Potwierdzają to także ci polscy oficerowie i żołnierze, którzy byli jako jeńcy wojenni wywiezieni do Rosji i stamtąd uciekli.

Kiedy wojsko ZSRR weszło do Wilna, żołnierze im [mieszkańcom] opowiadali, że teraz pójdą do Łotwy i Estonii. W kręgach oficerskich rozważano, że Rosja radziecka zaczeka, aż państwa zachodnioeuropejskie i Niemcy wykrwawią się we wzajemnej walce, i wtenczas komuniści uzyskają władzę nad całą Europą. Jednak szara masa wojska ZSRR sprawia wrażenie, że nie będzie mogła być poważnym przeciwnikiem niemieckiej, francuskiej albo angielskiej armii. Po wejściu do Wilna żołnierze przyznawali się robotnikom: „My vas bojaljisj, no teperj vidim, chto u vas njet orudij i tankov i uzhe nje boimsja" 47 . Jeden lekarz w szpitalu na prowincji opowiadał, że szła cała dywizja, kiedy partyzanci całkowicie nieoczekiwanie otworzyli ogień z kilku karabinów maszynowych. Rozpoczął się straszliwy bałagan i panika. Czołgi przejechały wielu swoich. Dowódca dywizji wtedy strasznie łajał swoich, że przestraszyli się kilku karabinów maszynowych. Potem przywieziono do szpitala większy transport rannych. Ranienia były przeważnie ze strony tylnej, złamane nogi i ręce. [...]

Źródło: LVVA, f. 2574, apr. 3, 1. 3248, lp. 13-30.

\section{Dokument 5. Sprawozdanie konsula Republiki Lotewskiej w Wilnie Felikssa Donassa dla dyrektora Departamentu Administracyjnego MSZ Teodorasa Anševicsa*. Ryga, 5 listopada 1939 r.}

19 września 1939 r. wojsko ZSRR weszło do Wilna i od tego czasu wszelka łączność ze światem zewnętrznym została przerwana. Jednak do konsulatu każdego dnia przybywali obywatele różnych państw, którzy, uciekając z Warszawy i innych części Polski, dotarli do Wilna, ale dalej nie mogli się dostać, ponieważ, z jednej strony, było im potrzebne pozwolenie na wyjazd od tymczasowego zarządu ZSRR, z drugiej strony - wiza tranzytowa

\footnotetext{
${ }^{47}$ „My was baliśmy, ale teraz widzimy, że wy nie macie armat i czołgów i już nie boimy się".

* Teodors Anševics (1900-1942) - dyplomata Łotwy, od 1939 r. dyrektor Administracyjnego Departamentu MSZ.
} 
na wjazd do Litwy od władz litewskich. Jednak konsul generalny Litwy w Wilnie wydawał takie wizy jedynie wtedy, gdy wnioskodawca mógł pokazać wizę Łotwy. No i oni zaczęli bombardować nasz konsulat swymi prośbami. Wielu nie miało paszportów zagranicznych i konsulat tłumaczył im, że ich prośby nie mają nadziei na pozytywny wynik. Chodziły pogłoski, że przedstawicielstwa Anglii na Litwie i Łotwie przejęły funkcje polskich konsulatów i wydadzą dokumenty zamiast zagranicznych paszportów. W związku z tymi pogłoskami ci, którzy utkwili w Wilnie, zrozpaczeni prosili o przyjęcie ich próśb w nadziei, że centralne urzędy Łotwy wezmą pod uwagę nadzwyczajne warunki i wykażą gotowość pomocy w wydostaniu się nieszczęsnych uchodźców z Wilna. Oni mają krewnych i powiązania w Anglii, Francji, Ameryce, Szwecji i innych krajach, które nie odmówią im pozwolenia na wjazd. Niech w każdym razie przyjmą ich prośby do naszego Ministerstwa Spraw Wewnętrznych. Ja im stanowczo powiedziałem, że obecnie nie ma żadnej możliwości, żeby wysłać te prośby. Oni jednak prośby wnieśli, prosząc o ich wysłanie przy pierwszej możliwości. Wielu prosiło, żeby wysłać telegramy w ich sprawie, jak tylko to będzie możliwe. Co parę dni przychodzili do konsulatu i pytali, jaka jest sytuacja. Niektórzy odmówili później wysyłania telegramów i konsulat zwrócił im wpłacone pieniędzy. Natomiast inni żądali wysyłania telegramów przy pierwszej możliwości. Biorąc pod uwagę moje wyjaśnienia, że bez wizy Szwecji i Estonii nasze Ministerstwo Spraw Zagranicznych pozwolenia na wjazd nie da, prosiciele wiz zaczęli prosić o przesłanie ich listów przy pierwszej możliwości tym osobom w Anglii, Ameryce, Szwecji i Łotwie, które mogłyby załatwić im wizy tych państw, które znajdują się poza Łotwą, mając nadzieję, że w takim wypadku nasze Ministerstwo Spraw Wewnętrznych nie będzie miało podstawy, żeby nie wydać wizy łotewskiej. Ponieważ konsul generalny Litwy informował mnie, że od razu po wejściu wojska litewskiego będę mógł wyjechać, a kiedy zacznie pracować poczta, nikt dokładnie nie wiedział, wtedy, od 18 października, zacząłem przyjmować te listy, które:

1) miały powiązanie z podanymi prośbami o wizy;

2) w których uchodźcy i miejscowi mieszkańcy powiadamiali swoich krewnych, że są żywi i zdrowi.

Ponieważ w taryfie konsularnej za przesyłanie [przeadresowanie] listów przewidziano opłatę konsularną, taką pobierałem: 18 października, dorównując 3 łaty 3,30 zł, a od 19 października - 15 zł, jeżeli prosiciele wiz 
i osoby wysyłające listy należały do kategorii bogatych uchodźców, którzy mieli złotych pod dostatkiem; listy biednych przesyłałem bez zapłaty.

Po wejściu bolszewików jedynymi zyskami konsulatu były wyżej wymienione wpłaty za wizy wjazdowe. Jeśli by ich zabrakło, konsulat znalazłby się w okropnej sytuacji, ponieważ wpłaconych do Banku Łotwy dopłat ministerialnych nie można było sprowadzić do Wilna, a ministerstwo, przy najlepszej chęci, też nie mogło konsulatowi wysłać ani pieniędzy, ani żywności. Obecnie wpłacone złote nie mają żadnej wartości, ponieważ ani w Kownie, ani w Rydze ich nie przyjmują.

Biorąc pod uwagę, że Pan nie zgadza się z czynnością konsulatu odnośnie do przyjmowania listów w tym nadzwyczajnym wypadku i w powiązaniu z naszą osobistą rozmową, oddaję za przesyłanie listów wzięte pieniądze, w sumie 595,80 zł, do Funduszu Obrony Łotwy. Ale ponieważ złote w Rydze nie mają żadnej wartości, uprzejmie proszę ich kontrwartość - 183,00 łatów wpłacić do Funduszu Obrony z dopłat ministerstwa konsulatowi, utrzymując:

1) od dopłaty listopadowej - 83,00 łatów;

$$
\begin{aligned}
& \text { grudniowej - 50,00; } \\
& \text { styczniowej - 50,00. }
\end{aligned}
$$

Źródło: LVVA, f. 2574, apr. 3, 1. 3248, lp. 10-12.

\section{Dokument 6. Sprawozdanie konsula Republiki Lotewskiej w Wilnie Fe- likssa Donassa dla poselstwa w Kownie. Wilno, 16 listopada 1939 r.}

Uzupełniając swoje sprawozdanie z 13 listopada nr 486/VII.G, konsulat ma zaszczyt oświadczyć, że urzędy litewskie wymieniają każdej rodzinie 150 złotych na 5 litów. Pozostałe pieniądze mają być zdeponowane w którymś z banków do 20 listopada tego roku. Potem będzie ogłoszony nowy kurs. Zwróciło się do mnie kilku obywateli Łotwy, którzy oświadczyli, że litewskie urzędy odmawiają wymiany i przyjęcia w depozyt ich złotych. Dzisiaj zwróciłem się do delegatury litewskiej, gdzie mi Pan Trimakas wyjaśnił, że wymiana złotych to akcja dobroczynna, która odnosi się jedynie do miejscowych mieszkańców, ale nie do cudzoziemców. W taki sposób nasi obywatele moga wymienić swoje złote tylko na czarnym rynku, a to jest zakazane. Jakie jest wyjście z tej sytuacji? 
Oprócz tego nasi obywatele, głównie studenci, którzy w sprawach rodzinnych na jakiś czas powinni wyjechać do Łotwy, ale którzy chcą wrócić z powrotem, żeby ukończyć studia na uniwersytecie wileńskim, skarżą się, że miejscowe urzędy litewskie wydają im jedynie pozwolenia na wyjazd, a odmawiają wydania pozwolenia na wjazd. Dlatego nasi obywatele boją się jechać, ponieważ nie wiadomo, czy przedstawicielstwa Litwy na Łotwie teraz wydadzą wizy powrotne do Wilna. To może zrobić tylko przedstawicielstwo Litwy na Łotwie lub Ministerstwo Spraw Wewnętrznych [Litwy] w Kownie. Konsulat uprzejmie prosi poselstwo o wyjaśnienie, czy nasi obywatele mieszkający stale w okręgu wileńskim będą mogli wrócić do Wilna.

Przedstawiciel rządu litewskiego Pan Merkis ${ }^{48}$ przyjmie mnie 21 listopada o godz. 11-tej.

Źródło: LVVA, f. 2574, apr. 3, 1. 3248, lp. 5.

\section{Streszczenie}

Przez ostatnie 17 lat przed wybuchem II wojny światowej konsulem Łotwy w Wilnie był zawodowy dyplomata Felikss Donass. We wrześniu 1939 r. pozostał on w mieście i przesyłał do swoich władz (łotewskiego Ministerstwa Spraw Zagranicznych, Poselstwa Łotwy w Moskwie) doniesienia o zachodzących w nim wydarzeniach. Jego sprawozdania zaczynają się 17 września, a kończą 16 listopada 1939 r. Są przechowywane w Państwowym Archiwum Historycznym Łotwy w Rydze (Latvijas Valsts vēstures arhīvs).

Sprawozdania Felikssa Donassa z Wilna to niezwykle ciekawe źródła, ukazują bowiem skomplikowaną sytuację i wydarzenia w Wilnie na początku II wojny światowej widziane oczami łotewskiego konsula, okupację radziecką, reakcję na nią różnych grup społecznych i wejście armii litewskiej jesienią 1939 r. Przedstawiają także sytuację konsulatu Łotwy - państwa, które już w pierwszym dniu wojny (1 września) deklarowało swoją neutralność w tym konflikcie.

\footnotetext{
${ }^{48}$ Antanas Merkys (1887-1955) - polityk i mąż stanu Litwy, kilkakrotnie minister obrony, w latach 1927-1932 gubernator Kłajpedy, w 1939 r. mianowany przedstawicielem rządu Litwy w Wilnie i ziemi wileńskiej.
} 
The consulate of Latvia in Vilnius and the reports from consul Felikss Donass written in autumn 1939 (summary)

Felikss Donass, a professional diplomat, had been the consul of Latvia in Vilnius for seventeen years before the outbreak of World War II. In September 1939 he stayed in the city and sent to his superiors (latvian Ministry of Foreign Affairs, and latvian mission in Moscow) reports on what was happening in the city. His first reports are dated September 17 and the last is from November 16, 1939. At the moment they are stored in the State Historical Archives of Latvia in Riga (Latvijas Valsts vēstures arhīvs). Donass's reports from Vilnius are a valuable source of information, because they show the complicated situation and happenings in the city at the beginning of World War II from the wiew of a latvian consul, including soviet occupation, reaction of different social groups to it and the enter of lithuanian army in autumn 1939. The reports also show the situation of the consulate of Latvia which was the country declaring neutrality in this conflict. 
